\title{
SINOCENTRISMO, EUROCENTRISMO E ESTUDOS ORIENTAIS
}

Teiiti Suzuki

Desde o século XVII A.C., os chineses, já com uma organização político-administrativa, vida urbana, escrita ideográfica e objetos de bronze de alto valor estético, eram o povo mais desenvolvido da Ásia Oriental que, isolada de outras áreas das civilizaçōes antigas - Mesopotâmia, Pérsia, Egito, Mediterrâneo Oriental e Índia - constituía o universo para os habitantes daquela região.

A China era o centro do mundo, cercado por povos menos cultos e considerados bárbaros e selvagens. Autodemoninava-se Império do Meio ou Flor do Meio, denominação essa que, mesmo atualmente, é adotada, tanto pela China Comunista, como pelo Regime de Formosa.

É o sinocentrismo, que é uma espécie de etnocentrismo, fenômeno universal de que partilham todos os povos, em maior ou menor grau.

Os chineses deram nomes específicos aos povos que os cercavam conforme a localização, isto é, conforme se achavam ao norte, ao sul, ao leste ou a oeste. Esses nomes são representados por ideogramas que significam seres sub-humanos, mais próximos do animal do que do homem. Traduzi-os acima, englobadamente, pelo termo bárbaros, de origem grega. $\mathrm{O}$ termo barbaroi significa povos que tinham língua, religião, usos e costumes, enfim, uma cultura diferente da dos gregos, sem conotação depreciativa.

No caso chinês, como se vê em sua história, o "bárbaro", uma vez incorporado à cultura chinesa, deixa de sê-lo, passando a integrar a Flor do Meio. O que, no entanto, caracteriza fundamentalmente o sinocentrismo é o fato de ele ser institucionalizado, erigindo-se em norma de direito internacional público: os povos que desejassem manter relações diplomáticas ou comerciais com o Império do Meio, tinham de se apresentar como seus vas- 
salos. É a prova da supremacia política, econômica e cultural de que a China desfrutava.

Houve, é verdade, épocas em que o sinocentrismo se mostrou mais atenuado. Ocorreu, por exemplo, em relação ao budismo que entrou na China por volta do último século a.C., através da Rota da Seda, então sob o controle do Império do Meio. $O$ budismo teve um grande surto a partir do século IV, numa época em que a metade norte - o berço da civilização chinesa - foi ocupada pelos nômades invasores e a fina flor da aristocracia teve que se refugiar ao sul do rio Yang-Tsé.

A grande tragédia abalou tão profundamente os valores tradicionais que se criou um ambiente propício para que a elite exilada, abandonando a arrogância milenar, aderisse à religião alienígena como um novo evangelho.

Os bárbaros conquistadores, isentos como eram de tal arrogância, aceitaram com entusiasmo a religião indiana. Movidos pelo zelo e excesso de "budistas novos", trouxeram monges famosos da Ásia Central recorrendo, por vezes, a operações militares, mandaram traduzir livros sagrados do sânscrito para o chinès e construíram grandes templos-cavernas com magnificas imagens de Budas e bodhisattvas.

Diga-se, de passagem, que eles também foram assimilados rapidamente à civilização chinesa ao conviverem com o povo conquistado. Eles, que habitavam a periferia do Império do Meio, sentiram sempre a fascinação pelas delícias daquela civilização. Dir-se-ia que se tratava dé "periferismo" como um antípoda do "centrismo" Nesse sentido, a Grécia, antes de chegar ao seu esplendor nos séculos V e IV a.C., era "periferista" em relação à Mesopotâmia e ao Egito.

A China foi de novo unificada no fim do século $\mathrm{Vl}$ e atingiu a idade de ouro nos séculos VII e VIII, sob a dinastia Tang, eminentemente cosmopolita e aberta ao mundo exterior.

Através da Rota da Seda, tanto terrestre, como marítima, esta pelo Mar da Arábia e pelo Oceano Índico, afluem ao Império do Meio mercadorias, culturas e gentes de regiões distantes como a Ásia Central, a Índia, a Pérsia, a Arábia, a Síria e Roma. Músicas, danças, teatros e jogos exóticos entram em voga. O encanto das garçonetes persas das casas de chá atrai os mandarins e playboys. "Chapéus e vestimentas bárbaras estavam na moda", registra, em tom de censura, a História de Tang, compilada por ordem imperial da dinastia seguinte. Aparecem mesquitas, sinagogas, templos zoroásticos, maniqueístas e igrejas cristãs nestorianas, contando estas, com a proteção imperial. 
É de se notar, no entanto, que a abertura não afetou aquela norma de relações diplomáticas, a que acima nos referimos, que continuou em pleno vigor.

Nas dinastias que se seguiram, o sinocentrismo tornou-se mais forte do que antes, o que causou não poucos dissabores à Flor do Meio.

Citarei um exemplo. Houve a guerra entre a China e o Japão no fim do século XVI, tendo como palco o território da Coréia, vassalo do Império. As hostilidades chegaram a um impasse e o armistício foi firmado, com a retirada das forças japonesas ao seu país. Ao ratificar o armistício, o Imperador chinês enviou uma mensagem ao chefe do governo japonês, concedendoIhe o título de Rei do Japão, que era a mais alta hierarquia da vassalagem. Esse ato de deferência, porém, feriu o brio do japonês que se considerava chefe de um estado independente e soberano. A guerra recomeçou, terminando só com a morte do chefe indignado. As hostilidades prolongadas exauriram o erário do Império. Recorreu-se a exações pesadas que provocaram revoltas populares. Mas a Corte, corroída pela corrupção da burocracia e pela luta palaciana entre facçōes antagônica, não conseguiu dominar a situação e a dinastia Ming desmoronou em meados do século XVII, quando o último imperador se suicidou, assediado pelas forças revoltosas no palácio imperial.

O país em anarquia foi uma presa fácil dos invasores vindos da Manchúria. Os primeiros imperadores manchus, "periferistas" no sentido acima mencionado, mostraram grande interesse pelas novidades européias trazidas pelos jesuítas. Tratados científicos foram traduzidos do latim para 0 chinês, em trabalho conjunto dos missionários e mandarins da Corte. Os textos traduzidos, porém, não tiveram repercussões suficientes na intelectualidade chinesa e ficaram adormecidos nas bibliotecas imperiais.

Com o passar dos tempos, os dominadores manchus assimilaram a cultura chinesa de tal maneira que se tornaram sinocentristas ferrenhos, 0 que dificultou a absorção das ciências e da tecnologia modernas da Europa. O Império do Meio tornou-se vítima vulnerável ante a sanha imperialista das potências ocidentais e mesmo do Japão que, "periferista" por excelência, conseguiu se "modernizar" mais rapidamente.

Como se sabe, a civilização ocidental nasceu do amálgama cultural formado de vários elementos, entre os quais se destacam como forças aglutinantes e propulsoras, o cristianismo, de origem semítica e as civilizações grega e latina. 
Sobre a civilização greco-romana, aprendemos nos bancos ginasiais o célebre verso latino: Graecia capta ferum victorem cepit. Pensei, então, que as coisas boas da Grécia foram recebidas por Roma e daí passaram aos bárbaros celtas, germânicos e eslavos, para finalmente constituirem um dos alicerces da civilização ocidental.

Mais tarde, fiquei sabendo que o enunciado do poeta romano era válido somente para as letras e as artes, mas Roma não cultivou nem Platão, nem Aristóteles, Pitágoras ou Euclides.

A filosofia e ciência gregas ficaram guardadas no Bizâncio, de onde foram levadas para a Síria, pelos cristãos nestorianos, expulsos de Constantinopla sob a acusação de heresia, no século V.

Os nestorianos traduziram para a língua síria, não só os textos da teologia bizantina mas também os da filosofia e ciência helênicas.

A sabedoria grega passou, em seguida, para a Pérsia sassânida, no século VI, onde os monarcas, amantes da cultura, incentivaram os estudos gregos, bem como os indianos.

A Pérsia foi conquistada pelos árabes e convertida ao islamismo no século VII. Em meados do século VIII, um abássida, isto é, descendente de Abas, tio de Maomé, derrotou o califado das Omiadas, com o apoio dos xiitas persas e fundou o califato dos Abássidas, com sede em Bagdá. No novo califado, a elite intelectual era formada de antigos funcionários da corte sassânida. Foi graças a essa elite persa e neelenistas sírios que os estudos gregos foram implantados no mundo islâmico. Nos dois séculos que se seguiram, os árabes passaram da fase da tradução e imitação para a da criação, como atestam os termos álgebra, álcool, alcali etc., desconhecidos pelos gregos.

Então, o Islão, com centros florescentes em Samarcando, na Ásia Menor, Bagdá na Mesopotâmia, Cairo no Egito e Córdoba na Espanha, constituía uma séria ameaça à integridade da Europa, cujos espíritos esclarecidos ficaram cônscios da necessidade de aprender o segredo da superioridade árabe. Foram buscá-la nas terras hispânicas à medida que foram sendo reconquistadas pela cristandade. Primeiro na Catalunha, no século XI e depois em Toledo, no século XII, onde encontraram a maravilha das filosofia e ciência gregas traduzidas em árabe, bem como das obras produzidas pelos comentadores e inovadores muçulmanos.

A pesquisa passou dos textos árabes para os originais em grego, rumo à criação da moderna ciência européia. 
Começa a decolagem da Europa. Sucedem-se a Renascença, dos séculos XV e XVI, as grandes navegações dos portugueses e espanhóis, idem, a revolução científica marcada por Galileu, Copérnico, Newton e outros, dos séculos XVII e XVIII e a revolução industrial nos séculos XVIII e XIX. A Europa, juntamente com os Estados Unidos que eram sua extensão, dominaram o mundo, de onde nasceu, como corolário, o eurocentrismo.

Maupassant, em sua crônica de viagem à Argélia, intitulada "Au Soleil", fala de seus habitantes árabes, nos seguintes termos: "Peuple étrange, enfantin, demeuré primitif comme à la naissance des races", e continua "aucun meuble pour rien garder, aucune industrie, aucun art, aucun savoir en rien"

Que arrogância! E que ignorância de um passado não muito remoto em que os árabes foram mestres dos europeus porque possuiam uma civilização incomparavelmente superior!

Essa opinião do grande escritor francês, no entanto, parece ser compartilhada pela grande maioria dos ocidentais. $O$ eurocentrismo, embora bem mais recente, está bem arraigado e apresenta o mesmo vício de seu antecessor chinês, a saber, a arrogância e o menosprezo por culturas alheias.

A arrogância que é filha da ignorância, acarreta, como vimos, a perda da flexibilidade do espírito, de que tanto necessita a humanidade para a solução dos graves problemas que hoje enfrenta.

$\mathrm{O}$ interesse por patrimônios culturais do Oriente e o incentivo aos Estudos Orientais que vêm crescendo no Ocidente são as reações mais do que oportunas contra esse estado de coisas.

A propósito, cumpre lembrar que a USP e o Colégio de México são os pioneiros desse movimento na América Latina, ao implantar, este, sob os auspícios da Unesco e aquela, por iniciativa própria, as disciplinas de Estudos Orientais ao seu currículo acadêmico, desde 1963.

(Trabalho apresentado na Primeira Semana de Letras, realizada na Faculdade de Filosofia, Letras e Ciências Humanas da Universidade de São Paulo, em outubro de 1989) 